\title{
WYZNANIOWA FORMA ZAWARCIA MAŁŻEŃSTWA CYWILNEGO A ZASADA RÓWNOUPRAWNIENIA ZWIĄZKÓW WYZNANIOWYCH
}

Zgodnie z obowiązującym stanem prawnym, związki wyznaniowe w Polsce mogą korzystać z przysługujących im praw zgodnie z zasadą równouprawnienia, bez względu na formę uregulowania ich sytuacji prawnej. Do katalogu przysługujących związkom wyznaniowym praw należy zaliczyć prawo do procedowania przy zawarciu małżeństwa zgodnie z prawem wewnętrznym związków wyznaniowych, które po spełnieniu dodatkowych kryteriów wywrze skutki cywilne. Korzystanie $\mathrm{z}$ tego prawa powinno być zgodne $\mathrm{z}$ konstytucyjną zasadą równouprawnienia związków wyznaniowych. W obecnym stanie prawnym, uprawnienie to może przysługiwać jedynie tym związkom wyznaniowym, których sytuacja prawna uregulowana jest w oparciu o umowę międzynarodową lub ustawę. Wyklucza to możliwość ubiegania się o to prawo przez związki wyznaniowe, których byt prawny opiera się o wpis do rejestru kościołów i innych związków wyznaniowych. Różnicowanie tych podmiotów w oparciu jedynie o kryterium formy uregulowania ich sytuacji prawnej budzi wątpliwości co do zgodności ze wskazaną konstytucyjną zasadą równouprawnienia. Dlatego w niniejszym opracowaniu przedstawiona zostanie treść konstytucyjnej zasady równouprawnienia związków wyznaniowych jako punkt wyjścia do kolejnych rozważań.

* Dr, Wydział Prawa, Prawa Kanonicznego i Administracji, Katolicki Uniwersytet Lubelski Jana Pawła II, Al. Racławickie 14, 20-950 Lublin, e-mail: abrama@kul.pl 
Następnie zbadana zostanie zgodność przepisów różnicujących sytuację prawną związków wyznaniowych w zakresie prawa do procedowania przy zawieraniu małżeństwa o podwójnym skutku z zasadą równouprawnienia związków wyznaniowych. W sposób szczególny zbadane zostanie kryterium, w oparciu o które dokonane zostało to zróżnicowanie, czyli forma uregulowania sytuacji prawnej związków wyznaniowych. Ponadto wskazane zostaną propozycje zmian prawnych dotyczących uregulowania wskazanego prawa związków wyznaniowych.

\section{TREŚĆ ZASADY RÓWNOUPRAWNIENIA ZWIĄZKÓW WYZNANIOWYCH}

Zasady określające relacje między państwem a związkami wyznaniowymi w Polsce określa w sposób kompleksowy art. 25 Konstytucji z dnia 2 kwietnia 1997 r. ${ }^{1}$ Jako pierwsza unormowana tam jest zasada równouprawnienia związków wyznaniowych, która jest cechą charakterystyczną demokratycznych państw świeckich ${ }^{2}$. Stoi ona na straży poszanowania różnorodności wyznaniowej i światopoglądowej społeczeństwa, ale także równości poszczególnych ludzi, gdzie podstawy upatrujemy w godności osoby ludzkiej ${ }^{3}$. Dlatego równość ludzi co do ich godności stanowi podstawę równouprawnienia kościołów i innych związków wyznaniowych ${ }^{4}$.

Należy zauważyć, że zasada równouprawnienia związków wyznaniowych swoją genezę czerpie z ogólnej zasady równości unormo-

${ }^{1}$ Dz. U. Nr 78, poz. 483 z późn. zm.

2 J. Krukowski, Konkordat polski. Znaczenie i realizacja, Lublin 1999, s. 58; P. Sobczyk, Konstytucyjna zasada równouprawnienia kościołów i innych zwiąków wyznaniowych, w: Problemy państwa i prawa, red. F. Prusak, Warszawa 2004, s. 21.

${ }^{3}$ J. Krukowski, Kościót i Państwo. Podstawy relacji prawnych, Lublin 2000, s. 277; P. Stanisz, Stosunki między państwem a kościołami i innymi związami wyznaniowymi $w$ Rzeczypospolitej Polskiej - zarys problematyki, w: Podstawy regulacji stosunków Państwo-Kościót w Rzeczypospolitej Polskiej i Republice Włoskiej (I Fondamenti della regolazione delle relazioni Stato-Chiesa nella Repubblica di Polonia e nella Repubblica Italiana), red. P. Czarnek, D. Dudek, P. Stanisz, Lublin 2010, s. 25.

${ }^{4}$ W Góralski, Wstęp do prawa wyznaniowego, Płock 2003, s. 96; J. Szymanek, Prawna regulacja wolności religijnej, „Studia Prawnicze” 2006, z. 2, s. 7; P. Bała, Pod wezwaniem Boga czy Narodu? Religia a ustrój - studium przypadku polskich konstytucji, Warszawa 2010, s. 222-223. 
wanej w art. 32 Konstytucji RP. Z uwagi na to, że każdy człowiek jest nosicielem tej samej godności, niezależnie od tego, do jakiego związku wyznaniowego należy, stanowi to podstawę równouprawnienia związków wyznaniowych ${ }^{5}$. Jest to przeniesienie podstawowego prawa człowieka, jednostki na podmiot zbiorowy, jakim jest związek wyznaniowy. Podkreśla to ścisłą korelację zasady równouprawnienia tych podmiotów z fundamentalną wartością, jaką jest godność osoby ludzkiej, unormowaną w art. 30 Konstytucji ${ }^{6}$.

Unormowana w obowiązującej obecnie Konstytucji RP zasada równouprawnienia związków wyznaniowych jest jedną z wielu konkretyzacji konstytucyjnej zasady równości ${ }^{7}$ Interpretacja zasady równouprawnienia związków wyznaniowych powinna uwzględniać również cały dorobek orzeczniczy Trybunału Konstytucyjnego, dotyczący konstytucyjnej zasady równości. Szczególne znaczenie ma tutaj wyrok z dnia 2 kwietnia 2003 r. (K 13/02) ${ }^{8}$. Dokonano w nim usystematyzowania wyjaśnianych już wielokrotnie kwestii dotyczących określenia zasady równości z art. 32 Konstytucji RP. W sposób szczególny zwróco-

${ }^{5}$ J. Krukowski, Konkordat polski, s. 58. Interesujące treści można znaleźć w nauczaniu Soboru Watykańskiego II. Przyjęta tam została zasada, że wolność należy się nie tylko Kościołowi Katolickiemu, ale także innym wspólnotom religijnym. Pogląd ten znalazł potwierdzenie w Dokumencie Stolicy Apostolskiej o wolności religijnej, do którego nawiązano na Konferencji w Sprawie Bezpieczeństwa i Współpracy w Europie w 1980 r., J. Krukowski, Kościót i Państwo, s. 97; P. Sobczyk, Konstytucyjna zasada, s. 27-28.

${ }^{6}$ J. Szymanek, Stosunki państwa ze zwiazkami wyznaniowymi $w$ świetle postanowień Konstytucji RP z 2 kwietnia 1997 r., w: Przestrzeń polityki i spraw wyznaniowych. Szkice dedykowane Profesorowi Januszowi Osuchowskiemu z okazji 75-lecia urodzin, red. B. Górowska, Warszawa 2004, s. 463-464.

${ }^{7}$ Inne egzemplifikacje zasady równości zawarte w Konstytucji to równouprawnienie kobiet i mężczyzn w art. 33; równy dostęp do dóbr kultury w art. 6; równość zrzeszania się w partiach politycznych w art. 11 ust. 1; dostęp do służby publicznej na jednakowych zasadach w art. 60; równa ochrona własności, innych praw majątkowych i dziedziczenia w art. 64 ust. 1; równy dostęp do świadczeń zdrowotnych finansowanych ze środków publicznych w art. 68 ust. 2; równy dostęp do wykształcenia w art. 70 ust. 4; równość wyborów do Sejmu w art. 96 ust. 2, wyborów prezydenckich w art. 127 ust. 1 oraz do organów stanowiących samorządu terytorialnego w art. 169 ust. 2. D. Dudek, Równouprawnienie Kościołów i zwiazków wyznaniowych na tle konstytucyjnych zasad prawa wyznaniowego w: Prawo wyznaniowe w systemie prawa polskiego. Materiały I Ogólnopolskiego Sympozjum Prawa Wyznaniowego (Kazimierz Dolny, 14-16 styczeń 2003), red. A. Mezglewski, Lublin 2004, s. 202.

${ }^{8}$ OTK-A 2003, nr 4, poz. 28. 
no tam uwagę na zasadę równouprawnienia związków wyznaniowych jako konkretyzację konstytucyjnej zasady równości ${ }^{9}$. Dlatego zasadę równości powinno się traktować jako lex generalis w stosunku do zasady równouprawnienia związków wyznaniowych. Zatem wszystkie unormowania prawne zawarte w aktach normatywnych podejmujących kwestie wyznaniowe powinny być zgodne z tymi konstytucyjnymi nakazami ${ }^{10}$.

Aby ustalić właściwe znaczenie zasady równouprawnienia związków wyznaniowych należy wskazać kryteria określające podmioty wchodzące do tej samej grupy. Należy odrzucić interpretacje egalitarystyczne, które utożsamiają równość z identycznością, co należy uznać za sprzeczne z zasadą sprawiedliwości rozdzielczej. Doprowadziłoby to do sytuacji niesprawiedliwych, polegających na ograniczeniu uprawnień związków wyznaniowych do tych, które przysługują jednemu, który przykładowo liczy najmniej wyznawców ${ }^{11}$. Dlatego za właściwą przesłankę równouprawnienia kościołów i innych związków wyznaniowych należy uznać określoną cechę wspólną, co potwierdza w swoim

${ }^{9}$ Zob. P. Borecki, M. Pietrzak, Glosa do orzeczenia z 2 IV 2003, K 13/02, „Państwo i Prawo" 2002, nr 8, s. 119-124; P. Borecki, M. Pietrzak, Glosa do wyroku Trybunatu Konstytucyjnego z dnia 2 kwietnia 2003 r., (sygn. Akt K 13/02), „Przegląd Sejmowy” 2003, nr 5, s. $96-113$.

${ }^{10} \mathrm{~S}$. Bożyk, Konstytucyjna zasada równouprawnienia kościołów i innych zwiąków wyznaniowych, w: Zasada równości w prawie. Konferencja naukowa. Rzeszów, 16 października 2003 r., red. H. Zięba-Załucka, M. Kijowski, Rzeszów 2004, s. 99-100.

${ }^{11}$ J. Krukowski, K. Warchałowski, Polskie prawo wyznaniowe, Warszawa 2000, s. 59. Autor ten twierdzi, że utożsamianie równości z prymitywnym egalitaryzmem w konsekwencji może doprowadzić do identycznego traktowania pod każdym względem podmiotów należących do jednego zbioru mimo istniejących różnic. Takie pojmowanie zasady równości ogranicza podmioty silniejsze podporządkowując je potrzebom i poziomowi podmiotów słabszych. J. Krukowski, Konstytucyjny model stosunków między państwem a kościotem w III Rzeczypospolitej, w: Prawo wyznaniowe w systemie prawa polskiego, s. 88-89. Zob. też: J. Matwiejuk, Konkordat z 1993 roku a pozycja prawna kościołów i zwiazków wyznaniowych nierzymskokatolickich, w: Prawo wyznaniowe w systemie prawa polskiego, s. 228-231; H. Misztal, Ustawy majowe - o gwarancjach wolności sumienia $i$ wyznania oraz o stosunku państwa do Kościoła Katolickiego w Polsce - z perspektywy 20 lat, w: Podstawy regulacji stosunków Państwo-Kościół w Rzeczypospolitej Polskiej i Republice Włoskiej, s. 99; K. Doktór-Bindas, Zasada równouprawnienia kościołów i zwiazków wyznaniowych, w: Podstawy regulacji stosunków Państwo-Kościót w Rzeczypospolitej Polskiej i Republice Włoskiej, s. 184-185. Odmiennego zdania jest P. Borecki, Zasada równouprawnienia wyznań w prawie polskim, „Studia z Prawa Wyznaniowego” 2007, t. 10, s. 134-138. 
orzecznictwie Trybunał Konstytucyjny. Zatem zasada równości polega na tym, że wszystkie podmioty charakteryzujące się w równym stopniu daną cechą istotną powinny być traktowane równo. Wynika z tego, że podmioty, które nie posiadają wspólnej cechy istotnej powinny być traktowane odmiennie. Ponadto, przy badaniu zgodności z zasadą równości należy wskazać podobieństwo określonych podmiotów oparte na wspólnej cesze istotnej lub faktycznej, która uzasadnia równe traktowanie. Ustalenie tego wymaga przeanalizowania celu i treści wskazanej normy prawnej. W omawianym orzeczeniu Trybunału Konstytucyjnego z dnia 2 kwietnia 2003 r. stwierdzono, że możliwe jest różnicowanie sytuacji prawnej podmiotów charakteryzujących się wspólną cechą istotną, jeśli spełnione są trzy przesłanki. Po pierwsze, należy przedstawić racjonalne uzasadnienie wprowadzonego różnicowania poprzez wskazanie związku z celem i treścią przepisów je wprowadzających. Po drugie, należy zachować odpowiednią proporcję pomiędzy wagą interesu, któremu różnicowanie ma służyć, a wagą interesów naruszonych. Po trzecie, różnicowanie podmiotów podobnych musi znajdować swoje uzasadnienie w wartościach, zasadach i normach chronionych konstytucyjnie. Dlatego przepisy prawa mogą wprowadzać różnicowanie sytuacji prawnej związków wyznaniowych w oparciu o usprawiedliwione podstawy i kryteria ${ }^{12}$. Zatem, jak wynika $\mathrm{z}$ omawianego orzeczenia, ,zasada równouprawnienia kościołów i związków wyznaniowych oznacza, że wszystkie kościoły i związki wyznaniowe posiadające wspólną cechę istotną powinny być traktowane równo. Jedno-

${ }^{12}$ Systemy prawne innych państw dopuszczają uzasadnione różnicowania. Orzecznictwo austriackiego Sądu Konstytucyjnego stoi na stanowisku, że różnicowanie związków wyznaniowych wobec prawa wymaga merytorycznego uzasadnienia, którego podstawą mogą być szczególne cechy danego kościoła czy związku wyznaniowego. Szwajcarskie orzecznictwo mówi o ,poważnych względach merytorycznych”, do których zalicza liczebne i historyczne znaczenie danego wyznania oraz zadania społeczne i charytatywne realizowane przez te podmioty. Z kolei orzecznictwo niemieckie posługuje się kryterium szczególnej skuteczności danego związku wyznaniowego o niezwykle ważnej pozycji w społeczeństwie i wynikającej z tego gwarancji trwałości. L. Garlicki, Wolność sumienia i wyznania w orzecznictwie konstytucyjnym - status wspólnot religijnych, „Biuletyn Trybunału Konstytucyjnego (numer specjalny)" 1999, s. 40; K. Orzeszyna, Podstawy relacji między państwem a kościołami w konstytucjach państw członkowskich i traktatach Unii Europejskiej. Studium prawnoporównawcze, Lublin 2007, s. 192. Zob. P. Borecki, Zasada równouprawnienia, s. 134-138. 
cześnie zasada ta zakłada odmienne traktowanie kościołów i związków wyznaniowych, które nie posiadają wspólnej cechy istotnej z punktu widzenia danej regulacji." Jako relewantne kryteria uzasadniające taką dyferencję w doktrynie wskazuje się tradycję, wkład w dziedzictwo narodowe kraju, charakter i misję wyrażającą się w dążeniu do urzeczywistniania praw i wolności człowieka oraz przynależność większości obywateli do związku wyznaniowego ${ }^{13}$.

W orzecznictwie Trybunału Konstytucyjnego podkreśla się również, że istnieje ścisły związek pomiędzy równością a sprawiedliwością rozdzielczą. Dlatego równouprawnienie związków wyznaniowych polega na jednakowym traktowaniu tych podmiotów przez prawo ze względu na określoną cechę w sytuacji, gdy charakteryzują się one nią

${ }^{13}$ D. Dudek, Równouprawnienie kościołów, s. 204-205. Na poziomie przepisów konstytucyjnych innych państw dopuszcza się różnicowanie pozycji prawnej poszczególnych kościołów. Za podstawę tego różnicowania uznaje się przykładowo w Rosji szczególny wkład danego wyznania w historię kraju, jego kulturę, z jednoczesnym zagwarantowaniem poszanowania innych wyznań, natomiast w Portugalii, zgodnie z konkordatem, państwo ma za zadanie uznać zasady doktryny i moralności chrześcijańskiej tradycyjnej dla kraju. Są też takie kraje, gdzie jeden związek wyznaniowy uzyskuje pozycję kościoła krajowego (Kościół katolicki na Malcie, Kościół prawosławny w Macedonii czy Kościół Ewangelicko-Luterański w Islandii). Inne konstytucje natomiast mimo braku wskazania konkretnego wyznania formułują kategorię religii czy wyznań uznanych, przykładu dostarcza tu Belgia. K. Orzeszyna, Podstawy relacji, s. 125-131, 333-334. Należy też wspomnieć o państwach skandynawskich, których ustawy zasadnicze określają szczególną pozycję jednego związku wyznaniowego jako oficjalnego, czy też państwowego. Zob. P. Florianowicz-Błachut, Luterański model otwartego państwa (quasi) wyznaniowego w Europie - od powiazania do przyjaznego rozdziału - kazus państw skandynawskich, w: Prawne granice wolności sumienia $i$ wyznania, red. R. Wieruszewski, M. Wyrzykowski, L. Kondratiewa-Bryzik, Warszawa 2012, s. 85-119. Takie unormowania stwarzają swoiste uprzywilejowanie wyznań większościowych w danym państwie. Podłożem tego obok wielu innych czynników niewątpliwie jest struktura wyznaniowa społeczeństwa. Takie różnicowanie wyznań wielokrotnie było rozpatrywane przez Sądy Konstytucyjne wielu państw. Powszechnie uznaje się, że zasada równości nie powinna być rozumiana bezwzględnie, a w sposób relatywny, co uzasadnia zakaz schematycznego traktowania wszystkich wspólnot religijnych. Takie działanie właśnie mogłoby doprowadzić do nierównego traktowania związków wyznaniowych. Dlatego ustawodawca może tworzyć przepisy determinujące różnicowanie sytuacji prawnej związków wyznaniowych pod warunkiem, że jest ono uzasadnione. Takie uzasadnienie odmienności w traktowaniu związków wyznaniowych może wynikać z cech szczególnych tych podmiotów, jednak nie może to doprowadzić do reglamentowania wolności funkcjonowania związków wyznaniowych. L. Garlicki, Wolność sumienia, s. 39-41. 
w identycznym stopniu. Oznacza to, że prawo nie może dokonywać różnicowania związków wyznaniowych, co do cechy, którą posiadają w identycznym stopniu. Jeśli więc między tymi podmiotami zachodzą znaczące różnice, każdy z nich powinien być potraktowany inaczej, stosownie do doniosłości tej różnicy. Dlatego zawsze, gdy chociaż jeden ze związków wyznaniowych charakteryzuje się pewną cechą odmienną w stosunku do pozostałych, wówczas ustawodawca nie tylko ma prawo, ale powinien to uwzględnić przy decydowaniu o prawnej sytuacji tego związku wyznaniowego ${ }^{14}$.

$\mathrm{Z}$ uwagi na różnice, jakimi charakteryzują się związki wyznaniowe w obszarze działania tych podmiotów, liczebność wyznawców, duchownych, budynków kultu oraz w wielu innych cechach różnicujących, równouprawnienie związków wyznaniowych nie ma charakteru formalnego. Nie jest właściwe także podejście redystrybutywne. Nakazywałoby ono nadanie w sposób równy uprawnień bez względu na różnice w liczebności czy znaczeniu wszystkich związków wyznaniowych. Nie jest właściwa również jej parytetowa interpretacja, zgodnie z którą większe związki wyznaniowe mają większe uprawnienia, a mniej liczne uprawnienia mniejsze. Dlatego za słuszne należy uznać stwierdzenie, że równość wobec prawa nakazuje traktowanie tych podmiotów bez żadnej dyskryminacji czy uprzywilejowania. Najwłaściwsze wydaje się posługiwanie tą samą miarą w stosunku do wszystkich zainteresowanych, należących do jednej grupy podmiotów oraz tymi samymi kryteriami przy dokonywaniu oceny ich sytuacji ${ }^{15}$. Konsekwencją takiej interpretacji jest uznanie jednakowej swobody tych podmiotów w zakresie realizowania funkcji religijnych określonych w art. 19 ust. 2 ustawy o gwarancjach wolności sumienia i wyznania ${ }^{16}$. Z tego wynika, że

${ }^{14}$ J. Szymanek, Stosunki państwa, s. 465; M. Olszówka, Interferencja zasad prawa wyznaniowego instytucjonalnego, „Przegląd Prawa Wyznaniowego” 2010, t. 2, s. 66; S. Bożyk, Konstytucyjna zasada, s. 99; P.A. Leszczyński, Zasada równouprawnienia kościotów $i$ innych zwiazków wyznaniowych $w$ świetle relacji między art. 25 ust. 1 a art. 25 ust. 5 Konstytucji RP, w: Zasady naczelne Konstytucji RP z 2 kwietnia 1997 roku. Materiały 52. Ogólnopolskiego Zjazdu Katedr Prawa Konstytucyjnego w Międzyzdrojach (27-29 maja 2010 r.), red. A. Bałaban, P. Mijal, Szczecin 2011, s. 399.

15 J. Szymanek, Stosunki państwa, s. 464.

${ }^{16}$ Dz. U. z 2005 r. Nr 231, poz. 1659 z późn. zm. Swoboda ta odnosi się do takich kwestii, jak: określenie własnej doktryny religijnej, wykonywanie kultu, udzielanie posług 
zgodnie z zasadą równouprawnienia związków wyznaniowych powinny być stworzone możliwości skorzystania z przyznanych poszczególnym związkom wyznaniowym uprawnień, co nie jest tożsame z nakazem ubiegania się o takie uprawnienia, czy też nakazem realizacji tych uprawnieńn ${ }^{17}$.

Zasada równouprawnienia związków wyznaniowych w aspekcie negatywnym natomiast, zakazuje uprzywilejowania tych podmiotów. Oznacza że akty prawne nie mogą zawierać norm tworzących specjalne uprawnienia dla jednego związku wyznaniowego w sytuacji, gdy inne mają takie same atrybuty. Państwo nie może zatem stwarzać sytuacji, w których pozycja jednego związku wyznaniowego jest korzystniejsza w zakresie pewnej sfery jego działalności w stosunku do pozostałych, mimo faktycznej aspiracji do realizowania podobnych uprawnień przez pozostałe związki wyznaniowe ${ }^{18}$. Zatem nie można dyskryminować związków wyznaniowych przykładowo przez różnicowanie jednych kosztem drugich np. w dostępie do środków społecznego przekazu, czy w zakresie subsydiowania związków wyznaniowych, kiedy ich sytuacja prawna lub faktyczna jest taka sama ${ }^{19}$. Konsekwencją istnienia tej zasady w polskim systemie prawnym jest wykluczenie możliwości powstania państwa wyznaniowego, ponieważ wiązałoby się to $\mathrm{z}$ uprzywilejowaniem jednego związku wyznaniowego ${ }^{20}$. Rozwiązanie

religijnych, rządzenie się w swoich sprawach własnym prawem, kształcenie oraz zatrudnianie duchownych. P. Stanisz, Naczelne zasady instytucjonalnych relacji państwo-kościót. Zasada równouprawnienia kościołów i innych związów wyznaniowych, w: A. Mezglewski, H. Misztal, P. Stanisz, Prawo wyznaniowe, Warszawa 2011, s. 77.

${ }^{17}$ P.A. Leszczyński, Zasada równouprawnienia kościołów, s. 400.

${ }^{18} \mathrm{Nie}$ narusza zatem zasady równouprawnienia związków wyznaniowych sytuacja, w której Kościół katolicki, jako związek wyznaniowy skupiający większość polskiego społeczeństwa (ok. 95\%) faktycznie oddziaływuje na życie publiczne i ma bardziej widoczną w nim pozycję w stosunku do pozostałych związków wyznaniowych. J. Krukowski, Konstytucyjny model stosunków między państwem a Kościołem, s. 89-90.

${ }^{19}$ H. Misztal, Wolność religijna, w: Prawo wyznaniowe, red. H. Misztal, Lublin 2000, s. $215-216$.

${ }^{20}$ J. Krukowski, Konkordat polski, s. 61. Warto przytoczyć tu słowa zaczerpnięte z Deklaracji o wolności religijnej, w której Sobór Watykański II wyraził pogląd, że: „Jeśli zważywszy na szczególne sytuacje narodów, zostaje przyznana jednej wspólnocie religijnej wyjątkowa pozycja cywilna w prawnym ustroju społeczeństwa, konieczne jest, aby jednocześnie było uznawane i respektowane prawo wszystkich obywateli i wspólnot religijnych 
to nie pozwala na ustanowienie kościoła państwowego, a nawet wspiera świecki charakter państwa ${ }^{21}$.

\section{FORMA REGULACJI SYTUACJI PRAWNEJ JAKO KRYTERIUM RÓŻNICUJĄCE}

Norma zawarta w art. 25 ust. 1 Konstytucji RP nakłada na wszystkie organy władzy publicznej nakaz równego traktowania wszystkich związków wyznaniowych bez względu na formę regulacji ich sytuacji prawnej. Nakaz ten w równym stopniu odnosi się do organów władzy ustawodawczej, sądowniczej i administracyjnej22. Jest swoistym zobowiązaniem ze strony państwa do równego traktowania związków wyznaniowych na gruncie prawa i nie może być postrzegana jako dążenie do faktycznie bezwzględnej identyczności tych podmiotów, co stałoby się naruszeniem omawianej zasady równouprawnienia. Związki wyznaniowe są organizacjami o charakterze religijnym, mającymi na celu zaspokajanie potrzeb religijnych osób do nich przynależnych. Trzeba zaznaczyć, że podmioty te charakteryzują się wieloma odrębnościami, z racji których ustawodawca uprawniony jest do różnicowania sytuacji prawnej podmiotów faktycznie nierównych w celu zabezpieczenia ich pozycji prawnej ${ }^{23}$.

do wolności w dziedzinie religijnej”. Podkreślony został także obowiązek państwa, „by nigdy w sposób otwarty, czy ukryty, nie była naruszana z powodów związanych z religią równość obywateli w dziedzinie praw, należących przecież do wspólnego dobra społeczności, i żeby wśród obywateli nie miała miejsca dyskryminacja”. J. Krukowski, Kościót i Państwo, s. 100-101.

${ }^{21}$ M. Pietrzak, Stosunki państwo-Kościół w nowej Konstytucji, „Państwo i Prawo” 1997, nr 11-12, s. 179. Podobne rozwiązania występują w systemach prawnych innych państw. Przykładem jest tutaj Hiszpania. W. Brzozowski, Konstytucyjne ramy stosunków państwo-kościól w Hiszpanii na przestrzeni XX wieku, w: Francuska Ustawa z 9 grudnia 1905 roku o rozdziale kościołów i państwa z perspektywy stu lat, red. M. Pietrzak, Warszawa 2007, s. $154-155$.

${ }^{22}$ M. Pietrzak, Nierzymskokatolickie Kościoły i związki wyznaniowe w Rzeczypospolitej Polskiej (1989-2000), w: Przestrzeń polityki i spraw wyznaniowych, s. 400-401.

${ }^{23}$ J. Szymanek, Prawo wyznaniowe w praktyce III RP (zagadnienia wybrane), ,Ruch Prawniczy, Ekonomiczny i Socjologiczny" 2006, z. 1, s. 97-100. Zob. też: tenże, Państwo Kościót w III RP. Między systemem rozdziału łagodnego a systemem państwa parawyznanio- 
Już ustawa o gwarancjach wolności sumienia i wyznania z dnia 17 maja 1989 r. unormowała w art. 9 ust. 2 pkt 3 nakaz równego traktowania wszystkich kościołów i innych związków wyznaniowych bez względu na formę regulacji ich sytuacji prawnej, określając go jako jedną z gwarancji wolności sumienia i wyznania ${ }^{24}$. Mimo takiego umiejscowienia, miała ona walor normy o randze konstytucyjnej, ponieważ była uważana za konsekwencję konstytucyjnej zasady równości prawa obywateli bez względu na wyznanie. Takie stanowisko widoczne było w orzecznictwie Trybunału Konstytucyjnego, czego przykładem jest orzeczenie z dnia 30 stycznia 1991 r. (K. 11/90) $)^{25}$, w którym opierając się na powyższych przepisach stwierdzono, że uregulowanie ustawowe odnoszące się do Kościoła katolickiego powinno być stosowane do innych kościołów i związków wyznaniowych. Natomiast w wyroku z dnia 5 maja 1998 r. (K. 35/97) ${ }^{26}$ Trybunał Konstytucyjny stwierdził, że uprawnienia poszczególnych związków wyznaniowych wpisane do ustaw określających ich sytuację prawną nie są unormowane w sposób wystarczający, dlatego wymaga to uzupełnienia w drodze innych aktów prawnych, a z uwagi na zasadę równouprawnienia powinno być to dokonane $\mathrm{w}$ formie jednolitej regulacji ${ }^{27}$. Zgodnie $\mathrm{z}$ treścią art. 9 ust. 2 pkt 3 ustawy o gwarancjach wolności sumienia i wyznania, ,Gwarancjami wolności sumienia i wyznania w stosunkach państwa z kościołami i innymi związkami wyznaniowymi są: (jest) równouprawnienie wszystkich kościołów i innych związków wyznaniowych, bez względu na formę uregulowania ich sytuacji prawnej"28. Oznacza to, że konstytucyjna norma z art. 25 ust. 1 formułuje wobec państwa nakaz zapewnienia wszystkim związkom wyznaniowym równych uprawnień, a w konsekwencji takich samych możliwości podejmowania działań,

wego, „Prawo i Religia” 2007, t. 1, s. 13-18; tenże, Konstytucyjna zasada równouprawnienia kościołów i innych związków wyznaniowych, „Studia Prawnicze” 2009, z. 1-2, s. 167.

${ }^{24}$ P. Stanisz, Naczelne zasady, s. 71.

${ }^{25}$ OTK 1991, poz. 2.

${ }^{26}$ OTK ZU 1998, nr 3, poz. 32.

${ }^{27}$ A. Mączyński, Wolność sumienia $i$ religii $w$ orzecznictwie polskiego Trybunatu Konstytucyjnego. Polski raport na XI Konferencję Europejskich Sąów Konstytucyjnych, „Biuletyn Trybunału Konstytucyjnego” 1999, nr 1, s. 54.

${ }^{28}$ P. Stanisz, Naczelne zasady, s. 71; K. Doktór-Bindas, Zasada równouprawnienia, S. 182. 
ale również zaniechania. Norma wskazanego wyżej konstytucyjnego artykułu nie zawiera w swojej treści żadnych kryteriów różnicujących zakres przysługujących związkom wyznaniowym uprawnień w zależności od formy regulacji ich prawnego statusu ${ }^{29}$.

Dla zakresu uprawnień związków wyznaniowych nie powinno mieć znaczenia, czy podmioty te funkcjonują w oparciu o ustawę indywidualną, czy też w oparciu o ustawę z dnia 17 maja 1989 r. o gwarancjach wolności sumienia i wyznania ${ }^{30}$. Zasada równouprawnienia związków wyznaniowych, unormowana w art. 25 ust. 1, odnosi się zarówno do formy regulacji sytuacji prawnej związków wyznaniowych, ale również do zakresu uprawnień przysługujących tym podmiotom wynikających również z Konkordatu ${ }^{31}$. Widoczna jest więc pewna prawidłowość, że już w momencie powstawania i uznawania związków wyznaniowych nie są one traktowane przez państwo tak samo. Oznacza to, że zgodne z zasadą równouprawnienia tych podmiotów jest istnienie odmiennych form uregulowania sytuacji prawnej poszczególnych związków wyznaniowych, które nie ma znamion dyskryminacji ${ }^{32}$.

Konstytucyjna zasada równouprawnienia związków wyznaniowych, unormowana w art. 25 ust. 1 odnosi się niewątpliwie do wszystkich tych podmiotów. Zatem niedopuszczalne jest dyskryminujące traktowanie związków wyznaniowych w zależności od różnej formy regulacji ich sytuacji prawnej ${ }^{33}$. Taka sytuacja oznaczałaby naruszenie konstytucyjnej zasady równości jednostek unormowanej w art. 32 tego aktu. Konsekwencją tego jest niedopuszczalność różnicowania uprawnień poszczególnych osób w realizacji prawa do wolności

${ }^{29}$ J. Szymanek, Konstytucyjna zasada równouprawnienia kościołów i innych zwiąków wyznaniowych, „Studia Prawnicze” 2009, z. 1-2, s. 168-169.

${ }^{30} \mathrm{~J}$. Matwiejuk, Konstytucyjna regulacja stosunków państwa z kościołami i innymi zwiazkami wyznaniowymi w III RP, „Administracja Publiczna. Zeszyty Naukowe Wyższej Szkoły Administracji w Białymstoku" 2005, nr 1, s. 217.

${ }^{31}$ J. Szymanek, Prawo wyznaniowe w praktyce III RP (zagadnienia wybrane), ,Ruch Prawniczy, Ekonomiczny i Socjologiczny” 2006, z. 1, s. 107.

${ }^{32}$ Zjawisko to określa się w doktrynie jako „multi-tiered structure of religious entities” (W. Cole-Durham, S. Ferrari). L. Garlicki, Wolność sumienia, s. 38.

${ }^{33}$ T.J. Zieliński, Mankamenty układowego regulowania sytuacji prawnej zwiazków wyznaniowych na podstawie art. 25 ust. 5 Konstytucji RP, „Przegląd Prawa Wyznaniowego” 2009, t. 1, s. 40; J. Szymanek, Prawo wyznaniowe, s. 100-101. 
religijnej z powodu przynależności do związków wyznaniowych, których sytuacja prawna regulowana jest w innej formie ${ }^{34}$. Oznaczałoby to również naruszenie zasady wynikającej z art. 30 Konstytucji RP, zgodnie z którą wszyscy ludzie są równi w swojej godności, z której wypływają ich prawa i wolności. Niedopuszczalnym jest, by kryterium różnicowania przysługujących praw człowieka była przynależność wyznaniowa $^{35}$, ponieważ równouprawnienie związków wyznaniowych jest konsekwencją nakazu równego traktowania każdej osoby przez władze publiczne bez względu na przyczynę ${ }^{36}$.

Mimo funkcjonowania różnych form regulacji sytuacji prawnej związków wyznaniowych, zakres uprawnień tych podmiotów powinien respektować zasadę równouprawnienia. Sam fakt istnienia różnych form regulacji sytuacji prawnej tych podmiotów nie narusza tej zasady, ponieważ związki wyznaniowe w swej istocie odznaczają się różnymi cechami, które również wpływają na formę regulacji ich statusu prawnego. W konsekwencji, jeden związek wyznaniowy funkcjonuje w oparciu o umowę międzynarodową i ustawę, 14 związków wyznaniowych funkcjonuje w oparciu o ustawy indywidualne oraz obecnie 161 związków wyznaniowych ${ }^{37}$ funkcjonuje w oparciu o wpis do rejestru kościołów i innych związków wyznaniowych, czyli ich sytuację prawną określają przepisy ustawy o gwarancjach wolności sumienia i wyznania. Dlatego też zróżnicowanie związków wyznaniowych w zakresie formy ich regulacji prawnej jest niewystarczającą podstawą dyferencjacji tych podmiotów w zakresie przysługujących im uprawnień. W rezultacie, sama forma uregulowania sytuacji prawnej związków wyznaniowych nie może być określona jako cecha relewantna pozwalająca na różnicowanie. Należy podkreślić, że cecha relewantna powinna być właściwie uzasadniona. Trudno natomiast odnaleźć uzasadnienie takiej cechy, jeśli wprowadzałaby ona możliwość różnicowania sytuacji prawnej związ-

${ }^{34}$ M. Pietrzak, Nowy Konkordat Polski, „Państwo i Prawo” 1994, nr 1, s. 16.

${ }^{35}$ J. Krukowski, Konstytucyjny model, s. 96.

${ }^{36}$ J. Szymanek, Klauzule wyznaniowe w Konstytucji RP, ,Studia z Prawa Wyznaniowego’ 2005, t. 8, s. 21; tenże, Stosunki państwa, s. 463.

${ }^{37}$ Dane o liczbie zarejestrowanych związków wyznaniowych na podstawie informacji ze strony Ministerstwa Administracji i Cyfryzacji, https://mac.gov.pl//relacje-panstwa-zkosciolami-przydatne-informacje [dostęp: 30.11.2014]. 
ków wyznaniowych w oparciu jedynie o formę uregulowania statusu prawnego tych podmiotów. To odmienności poszczególnych związków wyznaniowych podkreślające ich różnorodność powinny stanowić cechy istotne, relewantne. Należy zaznaczyć, że cechy relewantne powinny być właściwie uzasadnione, aby być podstawą determinującą różnicowanie sytuacji prawnej związków wyznaniowych, bez naruszenia zasady równouprawnienia tych podmiotów. W efekcie, bez względu na cechę różnicującą związki wyznaniowe, jaką jest forma uregulowania ich sytuacji prawnej, przysługujące im uprawnienia nie powinny doznawać różnicowań ${ }^{38}$. Dlatego związki wyznaniowe wpisane do rejestru powinny mieć zagwarantowaną możliwość korzystania ze wszystkich uprawnień, jakie przysługują takim podmiotom zgodnie $\mathrm{z}$ ich ustawami indywidualnymi ${ }^{39}$. Trzeba podkreślić, że z art. 25 ust. 1 Konstytucji RP wynika nakaz równego traktowania wszystkich związków wyznaniowych w zakresie ich praw i obowiązków, bez względu na formę regulacji ich sytuacji prawnej oraz bez względu na wynikające $\mathrm{z}$ tego niedogodności dla państwa. Dlatego wszystkie uprawnienia przysługujące związkom wyznaniowym w oparciu o ich ustawy indywidualne powinny być rozszerzone na związki wyznaniowe wpisane do rejestru ${ }^{40}$.

W przepisach podkonstytucyjnych widoczne jest różnicowanie sytuacji prawnej związków wyznaniowych wprowadzone w oparciu o cechę, jaką jest forma określenia ich sytuacji prawnej w zakresie prawa do stosowania wyznaniowej formy zawarcia małżeństwa cywilnego ${ }^{41}$. Zgodnie z art. 1 ust. 3 ustawy z dnia 25 lutego 1964 r. - Kodeks

${ }^{38}$ J. Szymanek, Konstytucyjna zasada, s. 169; tenże, Klauzule wyznaniowe, s. 21-22.

${ }^{39}$ J. Szymanek, Prawo wyznaniowe, s. 100-101; M. Pietrzak, Stosunki państwo-kościót, s. 181.

${ }^{40}$ Za T.J. Zieliński, Mankamenty układowego, s. 40-41.

${ }^{41}$ Zob. P. Majer, Matżeństwo jako przedmiot zainteresowania kościoła i państwa prawo kanoniczne a matżeństwo cywilne, w: Prawo wyznaniowe $w$ systemie prawa polskiego, s. 255-286; W. Góralski, Instytucja matżeństwa wyznaniowego o skutkach cywilnoprawnych jako wyraz zasady bilateralności w stosunkach państwowo-kościelnych w Polsce, w: Bilateralizm w stosunkach państwowo-kościelnych, red. M. Bielecki, Lublin 2011, s. 147-159; R. Sztychmiler, Wspótpraca państwa i Kościoła w prawnym regulowaniu kwestii dotyczacych matzeństwa i rodziny, w: Bilateralizm w stosunkach państwowo-kościelnych, red. M. Bielecki, Lublin 2011, s. 161-171. 
rodzinny i opiekuńczy ${ }^{42}$, możliwość zawarcia małżeństwa wyznaniowego, które wywrze skutki cywilne, może być przewidziana jedynie w ratyfikowanej umowie międzynarodowej lub ustawie regulującej stosunki między państwem a kościołem albo innym związkiem wyznaniowym. Zatem uprawnienie to może przysługiwać jedynie zainteresowanym związkom wyznaniowym, których sytuacja prawna uregulowana została $\mathrm{w}$ oparciu o ustawy regulujące ich status prawny ${ }^{43}$ oraz Konkordat ${ }^{44}$. Wydaje się zasadne przyznanie możliwości korzystania

${ }^{42}$ Dz. U. Nr 9, poz. 59 z późn. zm.

${ }^{43}$ Zob. art. 15a ustawy z dnia 17 maja 1989 r. o stosunku Państwa do Kościoła Katolickiego w Rzeczypospolitej Polskiej (Dz. U. Nr 29, poz. 154 z późn. zm.); art. 12a ustawy z dnia 4 lipca 1991 r. o stosunku Państwa do Polskiego Autokefalicznego Kościoła Prawosławnego w Rzeczypospolitej Polskiej (Dz. U. Nr 66, poz. 287 z późn. zm.); art. 12a ustawy z dnia 13 maja 1994 r. o stosunku Państwa do Kościoła Ewangelicko-Augsburskiego w Rzeczypospolitej Polskiej (Dz. U. Nr 73, poz. 323 z późn. zm.); art. 8a ustawy z dnia 13 maja 1994 r. o stosunku Państwa do Kościoła Ewangelicko-Reformowanego w Rzeczypospolitej Polskiej (Nr 73, poz. 324 z późn. zm.); art. 9a ustawy z dnia 30 czerwca 1995 r. o stosunku Państwa do Kościoła Polskokatolickiego w Rzeczypospolitej Polskiej (Dz. U. Nr 97, poz. 482 z późn. zm.); art. 10a ustawy z dnia 30 czerwca 1995 r. o stosunku Państwa do Kościoła Adwentystów Dnia Siódmego w Rzeczypospolitej Polskiej (Dz. U. Nr 97, poz. 481 z późn. zm.); art. 10a ustawy z dnia 30 czerwca 1995 r. o stosunku Państwa do Kościoła Chrześcijan Baptystów w Rzeczypospolitej Polskiej (Dz. U. Nr 97, poz. 480 z późn. zm.); art. 11a ustawy z dnia 30 czerwca 1995 r. o stosunku Państwa do Kościoła Ewangelicko-Metodystycznego w Rzeczypospolitej Polskiej (Dz. U. Nr 97, poz. 479 z późn. zm.); art. 8a ustawy z dnia 20 lutego 1997 r. o stosunku Państwa do Kościoła Starokatolickiego Mariawitów w Rzeczypospolitej Polskiej (Dz. U. Nr 41, poz. 253 z późn. zm.); art. 11a ustawy z dnia 20 lutego 1997 r. o stosunku Państwa do Kościoła Zielonoświątkowego w Rzeczypospolitej Polskiej (Dz. U. Nr 41, poz. 254 z późn. zm.); art. 9a ustawy z dnia 20 lutego 1997 r. o stosunku Państwa do gmin wyznaniowych żydowskich w Rzeczypospolitej Polskiej (Dz. U. Nr 41, poz. 251 z późn. zm.).

${ }^{44}$ Zob. art. 10 Konkordatu między Stolicą Apostolską i Rzecząpospolitą Polską, podpisanego w Warszawie dnia 28 lipca 1993 r. (Dz. U. z 1998 r. Nr 51, poz. 318); zob. również: M. Winiarczyk-Kossakowska, Wolność sumienia i religii, „Studia Prawnicze” 2001, z. 1, s. 40-41; J. Krukowski, Zawarcie matżeństwa kanonicznego ze skutkami cywilnymi (Art. 10 Konkordatu między Stolica Apostolska a Rzeczapospolita Polska), „,Roczniki Nauk Prawnych" 1999, t. 9, z. 1, s. 227-228; A. Tunia, Znaczenie ustaw majowych w zakresie możliwości zawierania malżeństw wyznaniowych, w: Prawo wyznaniowe w Polsce (19892009). Analizy-dyskusje-postulaty, red. D. Walencik, Katowice-Bielsko-Biała 2009, s. 205-208; W. Góralski, Ochrona malzeństwa i rodziny w Konkordacie polskim z 1993 roku, w: Konkordat Polski w 10 lat po ratyfikacji. Materiaty z konferencji, red. J. Wroceński, H. Pietrzak, Warszawa 2008, s. 131-149; J. Krukowski, Procedura uznawania skutków cywilnych matżeństwa kanonicznego w prawie polskim, „Roczniki Nauk Prawnych” 2000, t. 10, z. 2, s. 205-224; A. Mezglewski, Przepisy wprowadzające w życie instytucję matżeń- 
z tego uprawnienia wszystkim zainteresowanym związkom wyznaniowym o uregulowanej sytuacji prawnej, bez względu na jej formę (także tym wpisanym do rejestru $)^{45}$. Przy dokonaniu omawianego rozróżnienia nie odwołano się do cechy relewantnej uzasadniającej powyższe różnicowania. Natomiast kryterium wskazujące na różną formę regulacji prawnej wydaje się niewystarczające. Wniosek ten potwierdza orzeczenie Trybunału Konstytucyjnego z dnia 2 kwietnia 2003 r. (K. 13/02), z którego wynika, że podmioty charakteryzujące się daną cechą relewantną w sytuacjach podobnych powinny być traktowane tak samo. Wskazane zostały tam również kryteria umożliwiające różnicujące traktowanie podmiotów, które nie posiadają w danej sytuacji cechy relewantnej, pozwalającej na ich odmienne traktowanie ${ }^{46}$. Taka decyzja organów władzy państwowej przy nadaniu uprawnienia do stosowania wyznaniowej formy zawarcia małżeństwa cywilnego narusza konstytucyjną zasadę równouprawnienia związków wyznaniowych ${ }^{47}$.

\section{POSTULATY ROZSZERZENIA PRAWA DO PROCEDOWANIA}

\section{PRZY ZAWARCIU MAŁŻEŃSTWA CYWILNEGO W FORMIE WYZNANIOWEJ}

Z przeprowadzonych rozważań wynika, że konieczna jest zmiana przepisów prawnych w kierunku przyznania możliwości korzystania z uprawnienia do wyznaniowej formy zawarcia małżeństwa cywilnego wszystkim zainteresowanym związkom wyznaniowym o uregulowanej sytuacji prawnej, bez względu na jej formę. Może to zostać dokonane przez zmianę ustawy z dnia 17 maja 1989 r. o gwarancjach wolności sumienia i wyznania, która w szczególności odnosi się do związków wyznanio-

stwa konkordatowego, „Roczniki Nauk Prawnych” 1999, t. 9, z. 1, s. 245-265; T.J. Zieliński, Stosowanie wyznaniowej formy zawarcia matżeństwa cywilnego poza Kościołem katolickim, „Państwo i Prawo” 2011, nr 2, s. 19-33.

${ }^{45}$ A. Mezglewski, Funkcje publiczne związków wyznaniowych, w: A. Mezglewski, H. Misztal, P. Stanisz, Prawo wyznaniowe, Warszawa 2011, s. 160; T.J. Zieliński, Mankamenty układowego, s. 41. Zob. również tenże, Rozciagnięcie prawa procedowania wyznaniowej formy zawarcia matżeństwa cywilnego na wspólnoty religijne wpisane do rejestru (propozycja de lege ferenda), „Przegląd Prawa Wyznaniowego” 2012, t. 4, s. 169-176.

${ }^{46}$ OTK-A 2003, nr 4, poz. 28.

${ }^{47}$ M. Pietrzak, Prawo wyznaniowe, Warszawa 2010, s. 256. 
wych wpisanych do rejestru oraz przepisów ustaw normujących prawo do zawarcia małżeństwa o podwójnym skutku, albo poprzez uchwalenie odrębnej ustawy regulującej to zagadnienie ${ }^{48}$. Jednak ze względu na doniosłość instytucji małżeństwa należy wprowadzić kryterium, po spełnieniu którego możliwe będzie skorzystanie ze wskazanego uprawnienia. Za interesującą należy uznać wskazywaną w doktrynie propozycję rozwiązania polegającego na konieczności przedłożenia przepisów własnego prawa małżeńskiego, gdzie określone zostaną elementy niezbędne do stosowania uprawnienia do zawarcia małżeństwa o podwójnym skutku. Przedłożenie to powinno być dokonane zgodnie z trybem właściwym dla zatwierdzenia statutu związku wyznaniowego. Ponadto, we właściwym do tego trybie, przepisy te powinny uzyskać aprobatę właściwego ministra ${ }^{49}$.

Zatem związki wyznaniowe bez względu na formę regulacji prawnej powinny mieć możliwość skorzystania z uprawnienia do procedowania przy zawarciu małżeństwa wyznaniowego, które wywrze skutki cywilne. Można dopuścić różnicowanie sytuacji prawnej związków wyznaniowych w tym zakresie poprzez wskazanie cechy relewantnej. W tym przypadku mogłoby być nią posiadanie własnych przepisów wewnętrznych określających prawo małżeńskie ${ }^{50}$. Powinno ono zostać zatwierdzone przez właściwego ministra. Po spełnieniu tego kryterium, czyli nabyciu danej cechy relewantnej zgodnie z zasadą równouprawnienia związków wyznaniowych, taki związek powinien mieć możliwość korzystania ze wskazanego uprawnienia.

W doktrynie należy zauważyć również inną ciekawą propozycję rozszerzenia prawa do procedowania przy zawarciu małżeństwa o podwójnym skutku na wszystkie związki wyznaniowe o uregulowanej sytuacji prawnej. Mogłoby to nastąpić poprzez wprowadzenie konieczności uzyskania właściwej licencji przez duchownego, która potwierdzałaby jego prawo do odbierania oświadczenia woli o zawarciu małżeństwa wyznaniowego, które wywrze skutki cywilne. W ten sposób krąg związków wyznaniowych uprawnionych w zakresie procedowania przy zawarciu małżeństwa o podwójnym skutku został-

\footnotetext{
${ }^{48}$ T.J. Zieliński, Rozciagnięcie prawa, s. 169-176.

${ }^{49}$ T.J. Zieliński, Mankamenty układowego, s. 41.

${ }^{50}$ J. Krukowski, K. Warchałowski, Polskie prawo, s. 60.
} 
by poszerzony również o te, które funkcjonują w oparciu o wpis do rejestru kościołów i innych związków wyznaniowych. Ponadto - co jest bardzo istotne - państwo nie straciłoby kontroli nad tak ważną instytucją, jak małżeństwo. Takie rozwiązanie wymaga wprowadzenia szeregu zmian w przepisach prawnych określających zasady zawarcia małżeństwa ${ }^{51}$. Należy zauważyć również podobne rozwiązanie mające na celu umożliwienie rozciągnięcia prawa do procedowania wyznaniowej formy zawarcia małżeństwa cywilnego na związki wyznaniowe wpisane do rejestru. Opiera się ono na stworzeniu instytucji ,świadka kwalifikowanego" mocą odrębnej ustawy, którym niekoniecznie musi być osoba duchowna. Ubiegający się o certyfikat „świadka kwalifikowanego" powinien spełnić wymogi określone prawem. Certyfikat wydawany byłby przez ministra właściwego do spraw wyznaniowych, który zobowiązany byłby do prowadzenia rejestru „świadków kwalifikowanych". Taki dokument potwierdzałby uprawnienie danej osoby do odbierania oświadczenia o zawarciu małżeństwa, które wywrze skutki cywilne $^{52}$. Należy podkreślić, że przedstawione propozycje zmian prawnych zapewniają bezpieczeństwo obrotu prawnego w zakresie zawierania małżeństwa o podwójnym skutku oraz nie pozostawiają kwestii zawarcia małżeństwa w zakresie dowolności związków wyznaniowych. Przede wszystkim wskazane rozwiązania prawne mogłyby doprowadzić do wyeliminowania przejawu naruszenia konstytucyjnej zasady równouprawnienia związków wyznaniowych i zadośćuczynić naglącej potrzebie dostosowania treści obowiązujących przepisów prawnych do wymogów zasady równouprawnienia.

\section{PODSUMOWANIE}

W polskim systemie prawnym mogą funkcjonować związki wyznaniowe, które mają uregulowaną sytuację prawną $\mathrm{w}$ oparciu o różne

${ }^{51}$ A. Tunia, Zasada równouprawnienia związów wyznaniowych $i$ jej ograniczenia $w$ zakresie zawierania matzeństw cywilnych $w$ formie wyznaniowej, „Opolskie Studia Administracyjno-Prawne" 2013, s. 102.

52 T.J. Zieliński, Rozciagnięcie prawa, s. 169-176. 
formy. Należy tu wymienić przede wszystkim umowę międzynarodową, jaką jest Konkordat, oraz ustawy regulujące status prawny poszczególnych związków wyznaniowych. Ponadto, związki wyznaniowe mogą uzyskać osobowość prawną w oparciu o wpis do rejestru kościolów i innych związków wyznaniowych. Funkcjonowanie wielu form regulowania statusu prawnego związków wyznaniowych nie narusza zasady równouprawnienia tych podmiotów.

Bez względu na formę uregulowania sytuacji prawnej, każdy związek wyznaniowy, zgodnie z zasadą równouprawnienia, powinien mieć możliwość uzyskania uprawnienia przysługującego innemu związkowi wyznaniowemu. Jednak w sytuacji, gdy zachodzą usprawiedliwione przesłanki, możliwe jest wprowadzenie różnicowania sytuacji prawnej związków wyznaniowych. Należy podkreślić, że sama forma uregulowania sytuacji prawnej związku wyznaniowego nie jest wystarczającym kryterium wprowadzenia różnicowania sytuacji prawnej związków wyznaniowych. Dlatego różnicowanie zakresu uprawnień związków wyznaniowych jedynie w oparciu o kryterium formy uregulowania ich sytuacji prawnej jest naruszeniem konstytucyjnej zasady równouprawnienia związków wyznaniowych. Przykładem takiego naruszenia jest możliwość korzystania z wyznaniowej formy zawarcia związku małżeńskiego jedynie w ramach związków wyznaniowych, których sytuacja prawna jest uregulowana w ustawie lub umowie międzynarodowej. Takiej możliwości obecne przepisy prawne pozbawiają związki wyznaniowe działające w oparciu o ustawę o gwarancjach wolności sumienia i wyznania. Dlatego konieczna jest zmiana przepisów prawa w celu zagwarantowania realizacji konstytucyjnej zasady równouprawnienia związków wyznaniowych także w zakresie wskazanego prawa.

\section{BIBLIOGRAFIA}

Bała P., Pod wezwaniem Boga czy Narodu? Religia a ustrój-studium przypadku polskich konstytucji, Warszawa 2010.

Borecki P., Pietrzak M., Glosa do orzeczenia z 2 IV 2003, K 13/02, „Państwo i Prawo" 2002, nr 8. 
Borecki P., Zasada równouprawnienia wyznań w prawie polskim, „Studia z Prawa Wyznaniowego" 2007, t. 10.

Borecki P., Pietrzak M., Glosa do wyroku Trybunału Konstytucyjnego z dnia 2 kwietnia 2003 r., (sygn. Akt K 13/02), „Przegląd Sejmowy” 2003, nr 5.

Bożyk S., Konstytucyjna zasada równouprawnienia kościołów i innych związków wyznaniowych, w: Zasada równości w prawie. Konferencja naukowa. Rzeszów, 16 października 2003 r., red. H. Zięba-Załucka, M. Kijowski, Rzeszów 2004.

Brzozowski W., Konstytucyjne ramy stosunków państwo-kościół w Hiszpanii na przestrzeni XX wieku, w: Francuska Ustawa z 9 grudnia 1905 roku o rozdziale kościołów i państwa z perspektywy stu lat, red. M. Pietrzak, Warszawa 2007.

Doktór-Bindas K., Zasada równouprawnienia kościołów i zwiąków wyznaniowych, w: Podstawy regulacji stosunków Państwo-Kościót w Rzeczypospolitej Polskiej i Republice Włoskiej (I Fondamenti della regolazione delle relozioni Stato-Chiesa nella Repubblica di Polonia e nella Repubblica Italiana), red. P. Czarnek, D. Dudek, P. Stanisz, Lublin 2010.

Dudek D., Równouprawnienie Kościołów $i$ związów wyznaniowych na tle konstytucyjnych zasad prawa wyznaniowego w: Prawo wyznaniowe w systemie prawa polskiego. Materiaty I Ogólnopolskiego Sympozjum Prawa Wyznaniowego (Kazimierz Dolny, 14-16 styczeń 2003), red. A. Mezglewski, Lublin 2004.

Florianowicz-Błachut P., Luterański model otwartego państwa (quasi) wyznaniowego $w$ Europie - od powiazania do przyjaznego rozdziatu - kazus państw skandynawskich, w: Prawne granice wolności sumienia i wyznania, red. R. Wieruszewski, M. Wyrzykowski, L. Kondratiewa-Bryzik, Warszawa 2012.

Garlicki L., Wolność sumienia $i$ wyznania w orzecznictwie konstytucyjnym status wspólnot religijnych, „Biuletyn Trybunału Konstytucyjnego (numer specjalny)" 1999.

Góralski W., Instytucja matżeństwa wyznaniowego o skutkach cywilnoprawnych jako wyraz zasady bilateralności w stosunkach państwowo-kościelnych w Polsce, w: Bilateralizm w stosunkach państwowo-kościelnych, red. M. Bielecki, Lublin 2011.

Góralski W., Ochrona malżeństwa i rodziny w Konkordacie polskim z 1993 roku, w: Konkordat Polski w 10 lat po ratyfikacji. Materiaty z konferencji, red. J. Wroceński, H. Pietrzak, Warszawa 2008.

Góralski W., Wstęp do prawa wyznaniowego, Płock 2003. 
Krukowski J., Konkordat polski. Znaczenie i realizacja, Lublin 1999.

Krukowski J., Konstytucyjny model stosunków między państwem a Kościołem w III Rzeczpospolitej, w: Prawo wyznaniowe w systemie prawa polskiego. Materiały I Ogólnopolskiego Sympozjum Prawa Wyznaniowego (Kazimierz Dolny, 14-16 styczeń 2003), red. A. Mezglewski, Lublin 2004.

Krukowski J., Kościół i Państwo. Podstawy relacji prawnych, Lublin 2000.

Krukowski J., Procedura uznawania skutków cywilnych matzeństwa kanonicznego w prawie polskim, „Roczniki Nauk Prawnych” 2000, t. 10, z. 2.

Krukowski J., Zawarcie matżeństwa kanonicznego ze skutkami cywilnymi (Art. 10 Konkordatu między Stolica Apostolska a Rzeczapospolita Polska), „Roczniki Nauk Prawnych” 1999, t. 9, z. 1.

Krukowski J., Warchałowski K., Polskie prawo wyznaniowe, Warszawa 2000. Leszczyński P.A., Zasada równouprawnienia kościołów i innych związków wyznaniowych $w$ świetle relacji między art. 25 ust. 1 a art. 25 ust. 5 Konstytucji RP, w: Zasady naczelne Konstytucji RP z 2 kwietnia 1997 roku. Materiały 52. Ogólnopolskiego Zjazdu Katedr Prawa Konstytucyjnego w Międzyzdrojach (27-29 maja 2010 r.), red. A. Bałaban, P. Mijal, Szczecin 2011.

Mączyński A., Wolność sumienia i religii w orzecznictwie polskiego Trybunatu Konstytucyjnego. Polski raport na XI Konferencję Europejskich Sądów Konstytucyjnych, „Biuletyn Trybunału Konstytucyjnego” 1999, nr 1.

Majer P., Małzeństwo jako przedmiot zainteresowania kościoła i państwa-prawo kanoniczne a matżeństwo cywilne, w: Prawo wyznaniowe w systemie prawa polskiego. Materiały I Ogólnopolskiego Sympozjum Prawa Wyznaniowego (Kazimierz Dolny, 14-16 stycznia 2003), red. A. Mezglewski, Lublin 2004.

Matwiejuk J., Konkordat z 1993 roku a pozycja prawna kościołów i związków wyznaniowych nierzymskokatolickich, w: Prawo wyznaniowe w systemie prawa polskiego. Materiaty I Ogólnopolskiego Sympozjum Prawa Wyznaniowego (Kazimierz Dolny, 14-16 stycznia 2003), red. A. Mezglewski, Lublin 2004.

Matwiejuk J., Konstytucyjna regulacja stosunków państwa z kościołami i innymi zwiąkami wyznaniowymi w III RP, „Administracja Publiczna. Zeszyty Naukowe Wyższej Szkoły Administracji w Białymstoku” 2005, nr 1.

Mezglewski A., Przepisy wprowadzające $w$ życie instytucję matzeństwa konkordatowego, „Roczniki Nauk Prawnych” 1999, t. 9, z. 1.

Mezglewski A., Misztal H., Stanisz P., Prawo wyznaniowe, Warszawa 2011. 
Misztal H., Ustawy majowe - o gwarancjach wolności sumienia $i$ wyznania oraz o stosunku państwa do Kościoła Katolickiego w Polsce - z perspektywy 20 lat, w: Podstawy regulacji stosunków Państwo-Kościót w Rzeczypospolitej Polskiej i Republice Włoskiej (I Fondamenti della regolazione delle relozioni Stato-Chiesa nella Repubblica di Polonia e nella Repubblica Italiana), red. P. Czarnek, D. Dudek, P. Stanisz, Lublin 2010.

Misztal H., Wolność religijna, w: Prawo wyznaniowe, red. H. Misztal, Lublin 2000.

Olszówka M., Interferencja zasad prawa wyznaniowego instytucjonalnego, „Przegląd Prawa Wyznaniowego” 2010, t. 2.

Orzeszyna K., Podstawy relacji między państwem a kościołami $w$ konstytucjach państw czlonkowskich i traktatach Unii Europejskiej. Studium prawnoporównawcze, Lublin 2007.

Pietrzak M., Nierzymskokatolickie Kościoły i zwiazki wyznaniowe w Rzeczypospolitej Polskiej (1989-2000), w: Przestrzeń polityki i spraw wyznaniowych. Szkice dedykowane Profesorowi Januszowi Osuchowskiemu z okazji 75-lecia urodzin, red. B. Górowska, Warszawa 2004.

Pietrzak M., Nowy Konkordat Polski, „Państwo i Prawo” 1994, nr 1.

Pietrzak M., Prawo wyznaniowe, Warszawa 2010.

Pietrzak M., Stosunki państwo-Kościót w nowej Konstytucji, „Państwo i Prawo" 1997, nr 11-12.

Sobczyk P., Konstytucyjna zasada równouprawnienia kościołów i innych zwiąków wyznaniowych, w: Problemy państwa i prawa, red. F. Prusak, Warszawa 2004.

Stanisz P., Stosunki między państwem a kościołami i innymi związkami wyznaniowymi w Rzeczypospolitej Polskiej - zarys problematyki, w: Podstawy regulacji stosunków Państwo-Kościót w Rzeczypospolitej Polskiej i Republice Włoskiej (I Fondamenti della regolazione delle relazioni Stato-Chiesa nella Repubblica di Polonia e nella Repubblica Italiana), red. P. Czarnek, D. Dudek, P. Stanisz, Lublin 2010.

Sztychmiler R., Wspólpraca państwa $i$ Kościoła w prawnym regulowaniu kwestii dotyczacych malżeństwa i rodziny, w: Bilateralizm $w$ stosunkach państwowo-kościelnych, red. M. Bielecki, Lublin 2011.

Szymanek J., Klauzule wyznaniowe w Konstytucji RP, „Studia z Prawa Wyznaniowego" 2005, t. 8.

Szymanek J., Konstytucyjna zasada równouprawnienia kościołów i innych zwiąków wyznaniowych, „Studia Prawnicze” 2009, z. 1-2. 
Szymanek J., Państwo - Kościót w III RP. Między systemem rozdziału łagodnego a systemem państwa parawyznaniowego, „Prawo i Religia” 2007, t. 1. Szymanek J., Prawna regulacja wolności religijnej, „Studia Prawnicze” 2006, z. 2.

Szymanek J., Prawo wyznaniowe $w$ praktyce III RP (zagadnienia wybrane), „Ruch Prawniczy, Ekonomiczny i Socjologiczny” 2006, z. 1.

Szymanek J., Stosunki państwa ze zwiąkami wyznaniowymi w świetle postanowień Konstytucji RP z 2 kwietnia 1997 r., w: Przestrzeń polityki i spraw wyznaniowych. Szkice dedykowane Profesorowi Januszowi Osuchowskiemи z okazji 75-lecia urodzin, red. B. Górowska, Warszawa 2004.

Tunia A., Zasada równouprawnienia związów wyznaniowych i jej ograniczenia $w$ zakresie zawierania matzeństw cywilnych $w$ formie wyznaniowej, „Opolskie Studia Administracyjno-Prawne” 2013.

Tunia A., Znaczenie ustaw majowych $w$ zakresie możliwości zawierania matżeństw wyznaniowych, w: Prawo wyznaniowe w Polsce (1989-2009). Analizy-dyskusje-postulaty, red. D. Walencik, Katowice-Bielsko-Biała 2009.

Winiarczyk-Kossakowska M., Wolność sumienia i religii, „Studia Prawnicze” 2001, z. 1.

Zieliński T.J., Mankamenty uktadowego regulowania sytuacji prawnej zwiąków wyznaniowych na podstawie art. 25 ust. 5 Konstytucji RP, „Przegląd Prawa Wyznaniowego" 2009, t. 1.

Zieliński T.J., Rozciagnięcie prawa procedowania wyznaniowej formy zawarcia matżeństwa cywilnego na wspólnoty religijne wpisane do rejestru (propozycja de lege ferenda), „Przegląd Prawa Wyznaniowego” 2012, t. 4. Zieliński T.J., Stosowanie wyznaniowej formy zawarcia matżeństwa cywilnego poza Kościołem katolickim, „Państwo i Prawo” 2011, nr 2.

THE RELIGIOUS FORM OF CIVIL MARRIAGE CONTRACTION AND THE PRINCIPLE OF EQUALITY OF RELIGIOUS DENOMINATIONS

\section{Summary}

According to the current law religious denominations in Poland may exercise their rights in accordance with the principle of equality regardless of the form in which their legal status is regulated. The catalogue of rights that religious denominations are entitled to include the right to proceeding 
with concluding the marriage in accordance with the internal law of religious denominations which after the fulfilment of additional criteria will have civil effects. Using this law should be consistent with the constitutional principle of equality of religious denominations. In the current law only those religious denominations are entitled to this right, whose legal status is regulated on the basis of an international agreement or a separate law. This eliminates the possibility of applying for the right religious denominations whose legal existence is based on the entry into the Register of Churches and other religious denominations. Differentiation of these entities based on the only criterion, which is the form of their legal status regulation raises doubts as to its compatibility with the indicated constitutional principle of equality. Regardless of the form of legal status regulation any religious denomination, in accordance with the principle of equality, should be able to exercise right which another religious denomination is entitled to. In case if there are justifiable reasons the legal position of religious communities may be made differentiated. It should be emphasized that the form itself of regulation of religious denomination is not a sufficient criterion for introduction differentiation of the of the legal status of religious denominations. Therefore, it is necessary to change the law in order to ensure the implementation of the constitutional principle of equality of religious denominations also within the right to use the religious form of civil marriage contraction.

Ttumaczenie wtasne autora

Key words: religious denominations, religious form of civil marriage contraction, the principle of equality of religious denominations, a form of legal status regulation

Słowa kluczowe: związek wyznaniowy, wyznaniowa forma zawarcia małżeństwa cywilnego, zasada równouprawnienia związków wyznaniowych, forma uregulowania sytuacji prawnej 